\title{
Effect of Gender, Age and Vaccine on Reactogenicity and Incapacity to Work after COVID-19 Vaccination: A Survey among Health Care Workers
}

Irit Nachtigall ( $\square$ irit.nachtigall@helios-gesundheit.de)

HELIOS Hospital Emil-von-Behring

\section{Marzia Bonsignore}

Evangelische Kliniken Gelsenkirchen

\section{Sven Hohenstein}

Heart Center Leipzig at University of Leipzig and Leipzig Heart Institute

Andreas Bollmann

Heart Center Leipzig at University of Leipzig and Leipzig Heart Institute

Rosita Günther

Helios Kliniken $\mathrm{GmbH}$

Cathrin Kodde

Helios Klinikum Emil von Behring

Martin Englisch

Helios Kliniken $\mathrm{GmbH}$

Parviz Ahmad-Nejad

Helios University Hospital Wuppertal, University of Witten/Herdecke

Alexander Schröder

Helios Kliniken GmbH

Corinna Glenz

Helios Kliniken $\mathrm{GmbH}$

Ralf Kuhlen

Helios Health $\mathrm{GmbH}$

Petra Thürmann

University Witten Herdecke Faculty of Health Witten

Andreas Meier-Hellmann

Helios Kliniken $\mathrm{GmbH}$

\section{Research Article}

Keywords: Vaccination, COVID-19, sex differences, circadian rhythm, reactogenicity, working capacity

Posted Date: November 30th, 2021 
DOI: https://doi.org/10.21203/rs.3.rs-1117313/v1

License: (c) (i) This work is licensed under a Creative Commons Attribution 4.0 International License. Read Full License

Version of Record: A version of this preprint was published at BMC Infectious Diseases on March 26th, 2022. See the published version at https://doi.org/10.1186/s12879-022-07284-8. 


\section{Abstract}

Background The aim of our study was to assess the influence of gender and age on reactogenicity by the different vaccines and their combinations. Further parameters were the reduction in working capacity after vaccination and the influence of the time of day when vaccines were administered.

Methods We conducted a survey on COVID-19 vaccinations and eventual reactions among employees of 89 hospitals of the Helios Group. On May 19th, 2021 employees received an invitation by e-mail from the chief medical officer with a link to the survey tool. Participation was voluntary and non-traceable. The survey was closed on June 21st, 2021.

Results 8,375 participants reported on 16,727 vaccinations. Reactogenicity was reported in $75 \%$ of COVID19 vaccinations. In $23 \%$ the capacity to work was affected. Major risk factors were female gender, younger age and vaccine other than BNT162b2. ChAdOx induced impairing reactogenicity mainly after the prime vaccination (70.5\%), while mRNA-1273 led to more pronounced reactions after the second dose $(71.7 \%)$. Heterologous prime-booster vaccinations with ChAdOx followed by either mRNA-1273 or BNT162b2 were associated with the highest risk for impairment (81.4\%). The time of day of the vaccinations showed no influence.

Conclusions Young women had the highest chance to experience reactogenicity and to be unable to work after COVID-19 vaccination. When vaccinating a large part of a workforce, especially in professions with a higher proportion of women like health care, employers as well as employees must be prepared for a noticeable amount of absenteeism.

Trial registration The study was approved by the Ethic Committee of the Aerztekammer Berlin on May 27th, 2021 (Eth-37/21) and registered in the German Clinical Trials Register (DRKS 00025745). The study was supported by the Helios research grant HCRI-ID 2021-0272.

\section{Background}

Since the WHO declared COVID-19 a pandemic in January 2020, the development and application of vaccines against the virus was classified as an important cornerstone in the fight against the virus. On December $21^{\text {st }}, 2020$ Biontech and Pfizer received authorization in the European Union for their mRNA COVID-19 vaccine (BNT162b2), followed on January $6^{\text {th }}, 2021$ by Moderna (mRNA vaccine mRNA-1273) and on January $29^{\text {th }}$ by AstraZeneca (vector vaccine ChAdOx).

After reports on thrombotic events following ChAdOx vaccinations $(1,2)$, several European countries restricted the vector vaccine to persons above a defined age limit (3). For younger persons who already received a prime immunisation with ChAdOx, a heterologous boost immunisation with an mRNA vaccine (BNT162b2 or mRNA-1273) was recommended (4).

Physical complaints after vaccinations are differentiated in reactogenicity and adverse effects. Type and frequency of reactogenicity and adverse effects related to the COVID-19 vaccines have been described in 
the studies performed regulatory approval (5-7). However, no information was provided regarding possible diverging results related to sex (i.e., due to genetic and hormonal factors) or gender (i.e., due to behavioural and lifestyle aspects). First real-world data shows a higher occurrence of physical complaints in women $(8,9)$. Few studies have addressed the safety of the newly applied heterologous vaccinations so far, showing contradictory results (10-13).

Therefore, the aim of our study was to assess the influence of gender and age on reactogenicity caused by the different vaccines and their combinations. Other parameters investigated were the reduction in the ability to work after vaccination and the influence of the time of day at which the vaccine was administered.

\section{Methods}

We conducted a survey addressing all employees of the Helios Kliniken Group in Germany. Helios is a privately owned company with 89 hospitals, ranging from small community structures to university hospitals. Consent of the group's work council was obtained.

On May $19^{\text {th }}, 2021$ all employees with a personal business email address received an invitation from the chief medical officer with a link to the survey tool. Additionally, a link was posted in the group's intranet page as 'Top News'. Participation was voluntary and non-traceable. A team of infectious diseases experts designed the survey; the translation of the included questions is displayed in figure 1. A separate questionnaire was completed for each vaccination. Incapacity to work was assessed using information from the questionnaire only, as was self-reported gender. The survey was closed on June $21^{\text {st }}, 2021$.

We classified physical complaints reported by the participants into two grades:

A. Significant impairment: (at least one symptom)

- Headache very strong/strong,

- chills, fever and general feeling of malaise

B. Mild impairment

- Headache mild/low

- pain at injection site, gastrointestinal complaints, skin rash, unusual fatigue, sweats, vertigo, muscle or joint pain and other.

To clarify that the classification of the impairment into significant and mild is based on our interpretation, the adjective assumed is prefixed in the results.

\section{Statistics}


For the description of the respondent characteristics and outcomes, we employed $\chi 2$ tests for binary variables. Effects were estimated in the R environment for statistical computing (version 4.0.2, 64-bit build).

For the multivariable analysis of the ordinal scales outcomes (a) grade of impairment (none $<$ mild $<$ significant) and (b) duration of the incapacity for work (none $<1$ or 2 days $<3$ or more days) we used ordered logistic regression (proportional odds logistic regression). We specified custom contrasts for the predictor variables (14). All variables entered the models as (one or multiple) contrasts comparing the current factor level to the baseline. The intercept represented the grand mean.

For the multivariable analysis of the ordinal scales outcomes (a) frequency of significant impairment (none < significant impairment after either vaccination < significant impairment after both vaccinations) and (b) frequency of incapacity to work (none < incapacity to work of minimum 1 day after either vaccination < incapacity to work of minimum 1 day after both vaccinations) we used ordered logistic regression. With the exception of the combination of vaccines, the specification of contrasts was identical to the others models. The combination of vaccines entered the models as repeated contrasts (sliding differences) comparing adjacent levels (the current level to the preceding one). For all tests we applied a two-tailed $5 \%$ error criterion for significance.

\section{Results}

In total, 8,375 of approximately 73,000 employees of the Helios Group participated in the survey and provided for information on 16,727 vaccinations. 80 participants did not provide any information on their gender, 26 declared to be diverse. Due to the low amount of diverse participants, no separate analysis was carried out. Of the remaining 8,269 participants, $74.1 \%$ were women; the proportion of women among all Helios employees by the time of the survey was $76.1 \%$. The characteristics of the participants are given in Table 1. Specifying for gender, only those who answered the question with men or women were included. The most common prime-boost vaccination was the homologous schedule with BNT162b2 (51\%), followed by the heterologous schedule ChAdOx + BNT162b2 (18\%).

The majority of participants (75\%) reported to have experienced some kind of physical complaints after either one or both vaccinations, in $41.2 \%$ of the participants we assumed a significant impairment caused by them. The physical complaint most commonly reported was pain at the injection site $(50.2 \%$ of all vaccinations), followed by general feeling of malaise (29.7\% of all vaccinations). Severe adverse effects were reported after nine vaccinations and included petechiae, thromboses and bleeding. An incapacity to work of one or more days was reported to have followed $25 \%$ of all vaccinations.

Table 1: Characteristics of Participants (see end of document file).

The occurrence of both reactogenicity and of incapacity to work differed between genders, vaccines and between first and second vaccination (figure 2). Anaphylactic reactions, which were rare, occurred to a similar degree in both genders. According to the classification of the reported physical complaints, we 
assumed the highest rate of significant impairment after the first vaccination with ChAdOx $(70.5 \%)$ and after the second vaccination with mRNA-1273 (71.7\%). In line with this, an incapacity to work was most often reported to have followed the first vaccination with ChAdOx (33.6\% 1-2 days, 10\% 3 or more days) and the second vaccination with mRNA-1273 (29,5\% 1-2 days, 9.2\% 3 or more days).

Figure 3 depicts the corresponding analysis focusing on vaccine combination as opposed to single vaccines. The homologue schedules with BNT162b2 showed the highest rate of participants reporting no major reactogenicity (49.4\%) or no incapacity to work (79.2\%) after either one of the vaccinations. According to the classification of the reported physical complaints, we assumed the highest frequency of significant impairment after both vaccination in participants vaccinated with a heterologous schedule ChAdOx followed either BNT162b or mRNA-1273 (35.3\%). An incapacity to work after both vaccinations was also most often reported for the same heterologous schedule (53.7\%).

We conducted multivariable analyses addressing single vaccinations (table 2) and their combinations (table 3). In all analyses, the factors of older age, male gender and vaccine BNT162b were independently associated with lower odds ratio for both impairing reactogenicity and incapacity to work. In the comparison of vaccine schedules, the heterologous combination ChAdOx + BNT162b or mRNA-1273 showed the highest odds ratios. The homologue schedules with ChAdOx and mRNA-1273 had a comparable risk. A homologue prime-booster vaccination with BNT162b was associated with the lowest odds ratios. The time of vaccination (morning vs afternoon) had no significant influence.

Table 2. Multivariable Analyses of risk factors for an impairment caused by reactogenicity or incapacity to work (single vaccinations) (see end of document file).

Table 3. Multivariable Analyses of risk factors for an impairment caused by reactogenicity or incapacity to work (prime-booster vaccinations) (see end of document file).

\section{Discussion}

In the cohort of this study, a high rate of impairing reactogenicity and a substantial loss of working days after COVID-19 vaccinations was reported. Major risk factors were female gender, younger age and vaccine other than BNT162b2. ChAdOx induced reactogenicity mainly after the prime vaccination, while mRNA-1273 led to more pronounced reactions after boostering. Heterologous prime-booster vaccinations with ChAdOx followed by either mRNA-1273 or BNT162b2 were associated with the highest risk for impairments. The time of day of the vaccinations showed no influence.

The effect of age on reactogenicity has already been described in previous large-scale studies $(5,6,15)$. Data on sex or gender differences are still scarce, as results of previous trials were not reported in a gender-sensitive manner. In an analysis of the Centers for Disease Control and Prevention based on 13.7 million COVID-19 vaccine doses given in the USA, $79 \%$ of all adverse effects reported to the agency came from women, even though only $61 \%$ of the vaccines had been administered to them (9). Further studies on real-world data showed a similar tendency towards a higher reactogenicity in females $(8,11)$. 
Sex-related differences in the occurrence of adverse reactions have been disclosed for several drugs, with females suffering more often from side effects than males (16). Until the early 1990s, women of childbearing age were kept out of drug trials in order to avoid exposing unknown pregnant women to drugs. Regimens developed on men were applied on women without further research on the possible effects of sex on a drug's efficacy and safety. In consequence, $80 \%$ of drug withdrawals from the U.S. market were ascribable to new health risks found in women (17). This gender discrepancy in side effects cannot only be explained by differences in pharmacokinetics (18), but also in pharmacodynamics, as shown by the higher risk for QT-prolongation (19).

Sex and gender differences influence immune response and outcome to infectious diseases. In general, females tend to have an enhanced immune response compared to males, which is held responsible for the higher propensity for developing autoimmune disease (20). They have a more intense cellular and humoral immune response to vaccinations $(21,22)$, resulting in both, higher efficacy and more adverse effects (23) including anaphylactic reactions (24). One underlying mechanism is the sex hormone modulation of the immune system: antibody responses after influenza vaccine have been shown to be positively associated with concentrations of estradiol (25). However, sex differential effects of vaccines remain distinct in age (26), suggesting that genetic or other factors are likely to be involved.

The gender bias in our study is in line with earlier findings and was expected. It is all the more surprising, that the vaccine approval studies included a sufficient proportion of females, but did not disaggregate safety and efficacy according to sex or gender. As published recently, only $17.8 \%$ of the COVID-19 related clinical trials published in scientific journals until December 15, 2020 reported sex-disaggregated results or subgroup analyses (27).

In our cohort, the distribution of the different vaccines was not homogenous between men and women: men received BNT162b2 more often, while women were vaccinated more often with ChAdOx. The reason can only be speculated: the prioritization of specific professional groups in the beginning of the vaccination program, the gender distribution in these professional groups and the availability of the different vaccines over time might have played a role. Given that both, female gender and ChAdOx are associated with more reactogenicity, this will have led to an increased total occurrence of reactogenicity and incapacity to work.

Nearly half of the participants were unable to work at least one day after the first vaccination with ChAdOx; a comparable rate was reported for the booster vaccination with mRNA-1273. A similar survey among health care workers found even higher rates of $65.3 \%$ after ChAdOx prime and of $56.8 \%$ after mRNA-1273 booster (8). These rates are substantially higher than what could be expected according to the approval studies. The lack of personnel on such a large scale can endanger patient care and needs to be planned for when simultaneously vaccinating complete departments.

Why a vaccination with BNT162b2 in our study led to less reactogenicity and incapacity to work than the other two vaccines, is unclear. By the time of the survey, the image of ChAdOx had suffered from reports of major complications; this might have led to negative expectations and a higher awareness of vaccine 
reactions. However, this was not the case for mRNA-1273. A higher reactogenicity after mRNA-1273 compared to BNT162b2 has been described before; possible mechanisms were seen in higher dosage of

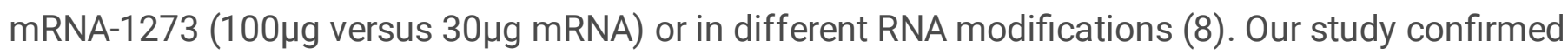
previous findings that while ChAdOx causes more reactogenicity at the prime immunisation, mRNA vaccines have more reactions effects at the booster $(5,6,15)$. Previous studies on safety of heterologous prime-boost COVID-19 vaccinations have shown diverging results. A participant-masked, randomised trial, found that heterologous vaccine schedules induced greater systemic reactogenicity following the boost dose than their homologous counterparts (10). An analysis of a survey among 1313 vaccinated persons showed that individuals who received heterologous prime-boost schedules were more likely to report severe reactogenicity after their second dose (11). Other studies from Germany have reported no difference in reactogenicity between homologous and heterologous schedules $(12,13)$.

Interestingly, we were not able to detect any influence of the time of day of vaccination. Interactions between vaccination timing and immunity response have been described before (28-30); therefore, we were expecting an effect on the reactogenicity.

\section{Strength and limitations of this study}

The strength of our study is the use of real-world data to assess reactogenicity and incapacity to work after different COVID-19 vaccines and schedules. The gender differences shown add evidence to an underexplored field; further studies addressing sex and gender specific immune responses to vaccines are needed.

The study suffers from several limitations. Due to data protection rules, there was no information on vaccination rate among staff; the response rate among vaccinated employees could therefore not be determined. The decision as to whether or not to participate to this survey might have depended on several reasons; persons who suffered from stronger vaccine reactions might have been more prone to share their experiences, leading to an overestimation of reactogenicity. Further, the addressed population -working-age persons with a high proportion of women- is not representative for the general population. We did not record the time interval between prime and booster immunisation. The recommended interval varied between vaccines and changed in the first months of the vaccination program in Germany; this could have influenced the results of the comparison between the homologous and heterologous schedule. This study targeted common reactogenicity; it was not powered to assess rare and serious adverse effects.

We assessed gender according the information given in the questionnaire, which reflects the personal identification rather than the biological/genetic status. Therefore, the results of our study refer to gender, women and men rather than to sex, females and males, which needs to be observed when comparing with other studies.

\section{Conclusions}


Young women had the highest chance to experience reactogenicity after a COVID-19 vaccination. When vaccinating a large part of a workforce, especially in professions with a higher proportion of women e.g. health care, employers have to expect a noticeable amount of absenteeism. To minimize reactogenicity, women should preferably receive a homologous prime-booster immunisation with BNT162b2. To reduce reactogenicity and adverse reactions in females, the designs of vaccines and vaccine strategies need to be sex-specific. Furthermore, it should be mandatory to report and publish sex-related variables in vaccine approval trials.

\section{Declarations}

\section{Ethics approval and consent to participate}

The study was approved by the Ethic Committee of the Aerztekammer Berlin on May 27 $7^{\text {th }}, 2021$ (Eth37/21) and registered in the German Clinical Trials Register (DRKS 00025745). The study was supported by the Helios research grant HCRI-ID 2021-0272. The process of data collection was in agreement with the European General Data Protection Regulation (GDPR) as well as the Helios' IT-security rules. Participants gave their consent to participate by accepting the disclaimer.

\section{Consent for publication}

Not applicable

\section{Availability of data and materials}

Helios Health and Helios Hospitals have strict rules regarding data sharing be-cause of the fact that health data are a sensible data source and have ethical restrictions imposed due to concerns regarding privacy. Access to anonymized data that support the findings of this study are available on request from the Leipzig Heart Institute (www.leipzig-heart.de). Please direct queries to the data protection officer (Email: info@leipzig-heart.de) and refer to study "eCaRe-COVID19" (HCRI ID 2020-0369).

\section{Competing interests}

The authors declare that they have no competing interests.

\section{Funding}

No funding was received

\section{Authors' contributions}

IN, MB, RG, ME, AS, CG and PT developed the questionnaire. ME, AS and CG helped with the dissemination of the questionnaire. IN, SH, CK, ME, PAN and AMH edited the results so that they were statistically processable. RK, SH and AB performed all statistical analyses of the data. IN, MB, PT and AMH drafted the manuscript. IN and CK drafted the graphical abstract. SH, AB, RG, CK, ME, PAN, AS, CG, RK, PT and AMH 
reviewed and edited the manuscript. All authors contributed to the final version of the manuscript and approved it for publication.

\section{Acknowledgements}

Not applicable

\section{References}

1. Greinacher A, Thiele T, Warkentin TE, Weisser K, Kyrle PA, Eichinger S. Thrombotic Thrombocytopenia after ChAd0x1 nCov-19 Vaccination. New England Journal of Medicine. 2021.

2. Schultz NH, Sørvoll IH, Michelsen AE, Munthe LA, Lund-Johansen F, Ahlen MT, et al. Thrombosis and thrombocytopenia after ChAdOx1 nCoV-19 vaccination. New England journal of medicine. 2021;384(22):2124-30.

3. Vygen-Bonnet S, Koch J, Bogdan C, Harder T, Heininger U, Kling K, et al. Beschluss der STIKO zur 3. Aktualisierung der COVID-19-Impfempfehlung und die dazugehörige wissenschaftliche Begründung. 2021.

4. Ständige Impfkommission beim Robert Koch-Institut. Mitteilung der Ständigen Impfkommission beim Robert Koch-Institut. Beschluss der STIKO zur 5. Aktualisierung der COVID-19-Impfempfehlung und die dazugehörige wissenschaftliche Begründung [Available from: https://www.rki.de/DE/Content/Infekt/EpidBull/Archiv/2021/Ausgaben/19_21.pdf? _blob=publicationFile. Accessed on 05 October 2021.

5. Voysey M, Clemens SAC, Madhi SA, Weckx LY, Folegatti PM, Aley PK, et al. Safety and efficacy of the ChAdOx1 nCoV-19 vaccine (AZD1222) against SARS-CoV-2: an interim analysis of four randomised controlled trials in Brazil, South Africa, and the UK. The Lancet. 2021;397(10269):99-111.

6. Baden LR, El Sahly HM, Essink B, Kotloff K, Frey S, Novak R, et al. Efficacy and safety of the mRNA-1273 SARS-CoV-2 vaccine. New England Journal of Medicine. 2021;384(5):403-16.

7. Polack FP, Thomas SJ, Kitchin N, Absalon J, Gurtman A, Lockhart S, et al. Safety and efficacy of the BNT162b2 mRNA Covid-19 vaccine. New England Journal of Medicine. 2020;383(27):2603-15.

8. Ziemann M, Görg S. Inability to Work After Corona Vaccination in Medical Staff. Deutsches Ärzteblatt International. 2021;118(17):298.

9. Gee J. First month of COVID-19 vaccine safety monitoring-United States, December 14, 2020 January 13,2021 . MMWR Morbidity and mortality weekly report. 2021;70.

10. Shaw RH, Stuart A, Greenland M, Liu X, Van-Tam JSN, Snape MD. Heterologous prime-boost COVID-19 vaccination: initial reactogenicity data. The Lancet. 2021;397(10289):2043-6. 
11. Powell AA, Power L, Westrop S, McOwat K, Campbell H, Simmons R, et al. Real-world data shows increased reactogenicity in adults after heterologous compared to homologous prime-boost COVID-19 vaccination, March- June 2021, England. Eurosurveillance. 2021;26(28):2100634.

12. Hillus D, Schwarz T, Tober-Lau P, Hastor H, Thibeault C, Kasper S, et al. Safety, reactogenicity, and immunogenicity of homologous and heterologous prime-boost immunisation with ChAdOx1-nCoV19 and BNT162b2: a prospective cohort study. medRxiv. 2021.

13. Schmidt T, Klemis V, Schub D, Mihm J, Hielscher F, Marx S, et al. Immunogenicity and reactogenicity of a heterologous COVID-19 prime-boost vaccination compared with homologous vaccine regimens. medRxiv. 2021.

14. Schad DJ, Vasishth S, Hohenstein S, Kliegl R. How to capitalize on a priori contrasts in linear (mixed) models: A tutorial. Journal of Memory and Language. 2020;110:104038.

15. Ramasamy MN, Minassian AM, Ewer KJ, Flaxman AL, Folegatti PM, Owens DR, et al. Safety and immunogenicity of ChAdOx1 nCoV-19 vaccine administered in a prime-boost regimen in young and old adults (COV002): a single-blind, randomised, controlled, phase 2/3 trial. The Lancet. 2020;396(10267):1979-93.

16. Soldin OP, Mattison DR. Sex differences in pharmacokinetics and pharmacodynamics. Clinical pharmacokinetics. 2009;48(3):143-57.

17. Safety GD. Most Drugs Withdrawn in Recent Years Had Greater Health Risk for Women. United States General Accounting Office. 2001.

18. Farkouh A, RiedI T, Gottardi R, Czejka M, Kautzky-Willer A. Sex-related differences in pharmacokinetics and pharmacodynamics of frequently prescribed drugs: a review of the literature. Advances in therapy. 2020;37(2):644-55.

19. Shah RR, Stonier PD. Withdrawal of prenylamine: perspectives on pharmacological, clinical and regulatory outcomes following the first QT-related casualty. Therapeutic advances in drug safety. 2018;9(8):475-93.

20. Angum F, Khan T, Kaler J, Siddiqui L, Hussain A. The prevalence of autoimmune disorders in women: a narrative review. Cureus. 2020;12(5).

21. Engler RJ, Nelson MR, Klote MM, VanRaden MJ, Huang C-Y, Cox NJ, et al. Half-vs full-dose trivalent inactivated influenza vaccine (2004-2005): age, dose, and sex effects on immune responses. Archives of internal medicine. 2008;168(22):2405-14.

22. Klein SL, Pekosz A. Sex-based biology and the rational design of influenza vaccination strategies. The Journal of infectious diseases. 2014;209(suppl_3):S114-S9. 
23. Giefing-Kröll C, Berger P, Lepperdinger G, Grubeck-Loebenstein B. How sex and age affect immune responses, susceptibility to infections, and response to vaccination. Aging cell. 2015;14(3):309-21.

24. Su JR, Moro PL, Ng CS, Lewis PW, Said MA, Cano MV. Anaphylaxis after vaccination reported to the vaccine adverse event reporting system, 1990-2016. Journal of Allergy and Clinical Immunology. 2019;143(4):1465-73.

25. Potluri T, Fink AL, Sylvia KE, Dhakal S, Vermillion MS, Vom Steeg L, et al. Age-associated changes in the impact of sex steroids on influenza vaccine responses in males and females. npj Vaccines. 2019;4(1):1-12.

26. Flanagan KL, Fink AL, Plebanski M, Klein SL. Sex and gender differences in the outcomes of vaccination over the life course. Annual review of cell and developmental biology. 2017;33:577-99.

27. Brady E, Nielsen MW, Andersen JP, Oertelt-Prigione S. Lack of consideration of sex and gender in COVID-19 clinical studies. Nature Communications. 2021;12(1):1-6.

28. Downton P, Early JO, Gibbs JE. Circadian rhythms in adaptive immunity. Immunology. 2020;161(4):268-77.

29. de Bree LCJ, Mourits VP, Koeken VA, Moorlag SJ, Janssen R, Folkman L, et al. Circadian rhythm influences induction of trained immunity by BCG vaccination. The Journal of clinical investigation. 2020;130(10):5603-17.

30. Benedict C, Cedernaes J. Could a good night's sleep improve COVID-19 vaccine efficacy? The Lancet Respiratory Medicine. 2021;9(5):447-8.

\section{Tables}

Table 1: Characteristics of Participants 


\begin{tabular}{|c|c|c|c|c|}
\hline & Women & Men & $\begin{array}{l}\mathrm{P}- \\
\text { value }\end{array}$ & $\begin{array}{l}\text { Odds ratio } \\
\text { (95\% confidence } \\
\text { interval) }\end{array}$ \\
\hline Participants (total $=8375$ ) & $\begin{array}{l}74.1 \% \\
(6,131 / 8269)\end{array}$ & $\begin{array}{l}25.9 \% \\
(2,138 / 8269)\end{array}$ & $\begin{array}{l}< \\
.01\end{array}$ & \\
\hline \multicolumn{5}{|l|}{ Age } \\
\hline $18-30$ & $14.0 \%(859)$ & $11.1 \%(237)$ & $\begin{array}{l}< \\
.01\end{array}$ & \\
\hline $31-40$ & $21.4 \%(1,314)$ & $23.5 \%(503)$ & .05 & \\
\hline $41-50$ & $24.4 \%(1,495)$ & $25.7 \%(549)$ & ns & \\
\hline $51-60$ & $31.1 \%(1,908)$ & $28.4 \%(607)$ & .02 & \\
\hline$>61$ & $7.2 \%(440)$ & $8.7 \%(187)$ & .02 & \\
\hline Missing or invalid data & $1.9 \%(115)$ & $2.6 \%(55)$ & ns & \\
\hline Recovered after COVID-19 & $1.8 \%(110)$ & $1.4 \%(28)$ & ns & \\
\hline \multicolumn{5}{|l|}{$1^{\text {st }}$ vaccine (total $\left.=8269\right)$} \\
\hline BNT162b2 & $59.1 \%(3,623)$ & $64.3 \%(1,375)$ & $\begin{array}{l}< \\
.01\end{array}$ & \\
\hline ChAdOx 2 & $34.4 \%(2,108)$ & $30.0 \%(641)$ & $\begin{array}{l}< \\
.01\end{array}$ & \\
\hline mRNA-1273 & $3.3 \%(203)$ & $2.9 \%(63)$ & ns & \\
\hline Missing or invalid data & $3.2 \%(197)$ & $2.8 \%(59)$ & ns & \\
\hline \multicolumn{5}{|l|}{$2^{\text {nd }}$ vaccine (total $\left.=8248\right)$} \\
\hline $\mathrm{BNT} 162 \mathrm{~b} 2 \mathrm{a}$ & $69.2 \%(4,244)$ & $69.2 \%(1,479)$ & ns & \\
\hline ChAdOx & $9.2 \%(564)$ & $9.3 \%(198)$ & ns & \\
\hline mRNA-1273 & $6.1 \%(371)$ & $6.0 \%(129)$ & ns & \\
\hline
\end{tabular}




\begin{tabular}{|c|c|c|c|}
\hline Missing or invalid data & $15.2 \%(931)$ & $15.4 \%(330)$ & ns \\
\hline No 2 nd vaccination & $0.3 \%(21)$ & $0.1 \%(2)$ & ns \\
\hline \multicolumn{4}{|c|}{ Vaccine combination, if $>1$ vaccination (total $=8246$ ) } \\
\hline $\mathrm{BNT} 162 \mathrm{~b} 2+\mathrm{BNT} 162 \mathrm{~b} 2$ & $49.5 \%(3,024)$ & $54.1 \%(1,155)$ & $\begin{array}{l}< \\
.01\end{array}$ \\
\hline mRNA-1273 + mRNA-1273 & $2.6 \%(158)$ & $2.3 \%(49)$ & ns \\
\hline ChAdOx + ChAdOx & $9.1 \%(554)$ & $9.1 \%(194)$ & ns \\
\hline ChAdOx + BNT162b2 & $19.0 \%(1,161)$ & $14.2 \%(304)$ & $\begin{array}{l}< \\
.01\end{array}$ \\
\hline ChAdOx + mRNA-1273 & $3.4 \%(206)$ & $3.7 \%(78)$ & ns \\
\hline $\begin{array}{l}\text { Missing information on } 1^{\text {st }} \text { or } \\
2^{\text {nd }} \text { vaccine }\end{array}$ & $16.5 \%(1,007)$ & $16.7 \%(356)$ & ns \\
\hline
\end{tabular}

\section{Time of day of vaccination}

Based on 13,876 vaccinations with information on time of day and gender

\begin{tabular}{|l|l|l|l|l|}
\hline Morning & $68.9 \%(7,148)$ & $68.3 \%(2,389)$ & $n s$ & \\
\hline Afternoon & $31.1 \%(3,230$ & $31.7 \%(1,109$ & $n s$ & \\
\hline
\end{tabular}

\section{Reactions (Multiple answers were possible)}

Based on 16,207 vaccinations with information on reactions and gender

\begin{tabular}{|l|l|l|l|l|}
\hline None & $23.1 \%(2,765)$ & $32.2 \%(1,358)$ & $<$ & $1.59(1.47-1.72)$ \\
\hline $\begin{array}{l}\text { Headache (very strong } \\
\text { strong) }\end{array}$ & $/ 17.7 \%(2,122)$ & $10.1 \%(425$ & $<$ & $0.52(0.47-0.58)$ \\
\hline Pain at the injection site & $52.2 \%(6,257)$ & $44.8 \%(1,887)$ & $<$ & $0.74(0.69-0.80)$ \\
& & & .01 & \\
\hline
\end{tabular}




\begin{tabular}{|c|c|c|c|c|}
\hline Chills & $21.7 \%(2,606)$ & $16.1 \%(677)$ & $\begin{array}{l}< \\
.01\end{array}$ & $0.69(0.63-0.76)$ \\
\hline Fever & $17.9 \%(2,143)$ & $13.9 \%(585)$ & $\begin{array}{l}< \\
.01\end{array}$ & $0.74(0.67-0.82)$ \\
\hline General feeling of malaise & $31.4 \%(3,765)$ & $26.5 \%(1,115)$ & $\begin{array}{l}< \\
.01\end{array}$ & $0.79(0.73-0.85)$ \\
\hline Unusual fatigue & $31.4 \%(3,762)$ & $25.3 \%(1,066)$ & $\begin{array}{l}< \\
.01\end{array}$ & $0.74(0.68-0.80)$ \\
\hline Rash & $2.5 \%(295)$ & $0.7 \%(28)$ & $\begin{array}{l}< \\
.01\end{array}$ & $0.27(0.18-0.39)$ \\
\hline Gastrointestinal complaints & $5.6 \%(670)$ & $2.5 \%(104)$ & $\begin{array}{l}< \\
.01\end{array}$ & $0.43(0.35-0.53)$ \\
\hline Sweats & $9.7 \%(1,169)$ & $7.5 \%(315)$ & $\begin{array}{l}< \\
.01\end{array}$ & $0.75(0.66-0.85)$ \\
\hline Vertigo & $10.2 \%(1,220)$ & $5.7 \%(242)$ & $\begin{array}{l}< \\
.01\end{array}$ & $0.54(0.47-0.62)$ \\
\hline Muscle or joint pain & $28.4 \%(3,412)$ & $22.8 \%(960)$ & $\begin{array}{l}< \\
.01\end{array}$ & $0.74(0.68-0.81)$ \\
\hline Other & $0.8 \%(814)$ & $3.7 \%(155)$ & $\begin{array}{l}< \\
.01\end{array}$ & $0.52(0.44-0.63)$ \\
\hline Anaphylactic reaction & $0.3 \%(31)$ & $0.2 \%(8)$ & ns & $0.73(0.34-1.60)$ \\
\hline
\end{tabular}

\section{Incapacity to work}

Based on 13,795 vaccinations with information on incapacity to work and gender

\begin{tabular}{|l|l|l|l|l|}
\hline None & $75.3 \%(7,746)$ & $81.9 \%(2,869)$ & $<$ & \\
& & & .01 \\
\hline $1-2$ days & $18.7 \%(1,924)$ & $14.3 \%(501)$ & $<$ & \\
& & & .01 & \\
\hline
\end{tabular}




\begin{tabular}{|l|l|l|l|l|}
\hline 3 ore more days & $6.0 \%(622)$ & $3.8 \%(133)$ & $<$ & \\
& & & .01 & \\
\hline
\end{tabular}

Table 2. Multivariable Analyses of risk factors for an impairment caused by reactogenicity or incapacity to work (single vaccinations) 


\begin{tabular}{|c|c|c|}
\hline Variable & $\begin{array}{l}\text { OR }(95 \% \text { confidence } \\
\text { interval })\end{array}$ & $\begin{array}{l}P \quad- \\
\text { value }\end{array}$ \\
\hline \multicolumn{3}{|c|}{$\begin{array}{l}\text { Assumed grade of impairment caused by reactogenicity (none vs. mild vs. significant) } \\
\text { Based on 12,387 vaccinations with complete information }\end{array}$} \\
\hline Age (31-40 vs. $18-30)$ & $0.80(0.71-0.90)$ & $\begin{array}{l}< \\
.001\end{array}$ \\
\hline Age (41-50 vs. $18-30)$ & $0.64(0.57-0.71)$ & $\begin{array}{l}< \\
.001\end{array}$ \\
\hline Age (51-60 vs. $18-30)$ & $0.46(0.41-0.52)$ & $\begin{array}{l}< \\
.001\end{array}$ \\
\hline Age (> 61 vs. $18-30)$ & $0.35(0.30-0.41)$ & $\begin{array}{l}< \\
.001\end{array}$ \\
\hline Time of vaccination (afternoon vs. morning) & $1.04(0.96-1.12)$ & ns \\
\hline Male gender & $0.66(0.58-0.76)$ & $\begin{array}{l}< \\
.001\end{array}$ \\
\hline Vaccination (second vs. first) & $2.00(1.75-2.29)$ & $\begin{array}{l}< \\
.001\end{array}$ \\
\hline Vaccine (ChAdOx vs. BNT162b2) & $2.43(2.16-2.74)$ & $\begin{array}{l}< \\
.001\end{array}$ \\
\hline Vaccine (mRNA-1273 vs. BNT162b2) & $2.08(1.72-2.51)$ & $\begin{array}{l}< \\
.001\end{array}$ \\
\hline Male gender $\times$ Vaccination (second vs. first) & $1.06(0.89-1.25)$ & ns \\
\hline Male gender $\times$ Vaccine (ChAdOx vs. BNT162b2) & $1.03(0.84-1.26)$ & ns \\
\hline Male gender $\times$ Vaccine (mRNA-1273 vs. BNT162b2) & $0.73(0.50-1.06)$ & ns \\
\hline $\begin{array}{l}\text { Vaccination (second vs. first) } \times \text { Vaccine }(\text { ChAdOx vs. } \\
\text { BNT162b2) }\end{array}$ & $0.05(0.04-0.06)$ & $\begin{array}{l}< \\
.001\end{array}$ \\
\hline
\end{tabular}


Vaccination (second vs. first) $\times$ Vaccine (mRNA-1273 $1.50(1.08-2.08)$ vs. BNT162b2 )

\section{Duration of an incapacity to work (none vs. $1-2$ days vs. $\geq 3$ days)}

Based on 11,105 vaccinations with complete information

\begin{tabular}{|c|c|c|}
\hline Age (31-40 vs. $18-30)$ & $0.68(0.58-0.78)$ & $\begin{array}{l}< \\
.001\end{array}$ \\
\hline Age (41-50 vs. $18-30)$ & $0.59(0.51-0.67)$ & $\begin{array}{l}< \\
.001\end{array}$ \\
\hline Age (51-60 vs. $18-30)$ & $0.47(0.41-0.54)$ & $\begin{array}{l}< \\
.001\end{array}$ \\
\hline Age (> 61 vs. $18-30)$ & $0.50(0.40-0.62)$ & $\begin{array}{l}< \\
.001\end{array}$ \\
\hline Time of vaccination (afternoon vs.morning) & $1.08(0.97-1.19)$ & ns \\
\hline Male gender & $0.72(0.61-0.85)$ & $\begin{array}{l}< \\
.001\end{array}$ \\
\hline Vaccination (second vs. first) & $1.59(1.30-1.96)$ & $\begin{array}{l}< \\
.001\end{array}$ \\
\hline Vaccine (ChAdOx vs. BNT162b2) & $2.12(1.76-2.54)$ & $\begin{array}{l}< \\
.001\end{array}$ \\
\hline Vaccine (mRNA-1273 vs. BNT162b2) & $1.87(1.42-2.46)$ & $\begin{array}{l}< \\
.001\end{array}$ \\
\hline Male gender $\times$ vaccination (second vs. first) & $0.88(0.65-1.19)$ & ns \\
\hline Male gender $\times$ vaccine (ChAdOx vs. BNT162b2) & $1.33(0.90-1.97)$ & $\mathrm{ns}$ \\
\hline Male gender $\times$ vaccine (mRNA-1273 vs. BNT162b2) & $1.17(0.73-1.987)$ & ns \\
\hline $\begin{array}{l}\text { Vaccination (second vs. first) } \times \text { vaccine }(\text { ChAdOx vs. } \\
\text { BNT162b2) }\end{array}$ & $0.05(0.03-0.06)$ & $\begin{array}{l}< \\
.001\end{array}$ \\
\hline
\end{tabular}




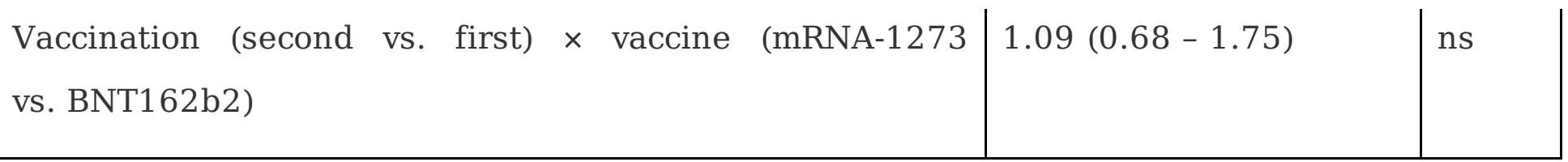

Table 3. Multivariable Analyses of risk factors for an impairment caused by reactogenicity or incapacity to work (prime-booster vaccinations) 


\begin{tabular}{|c|c|c|}
\hline Variable & $\begin{array}{l}\text { OR (95\% confidence } \\
\text { interval) }\end{array}$ & $\begin{array}{l}P \quad- \\
\text { value }\end{array}$ \\
\hline \multicolumn{3}{|l|}{$\begin{array}{l}\text { Frequency of an assumed significant impairment caused by } \mathbf{r} \\
\text { either one vs. after both vaccinations) } \\
\text { Based on } 6747 \text { vaccine combinations with complete information }\end{array}$} \\
\hline Age (31-40 vs. $18-30)$ & $0.77(0.66-0.90)$ & .001 \\
\hline Age (41-50 vs. 18-30) & $0.64(0.55-0.75)$ & $\begin{array}{l}< \\
.001\end{array}$ \\
\hline Age (51-60 vs. 18-30) & $0.47(0.40-0.55)$ & $\begin{array}{l}< \\
.001\end{array}$ \\
\hline Age (> 61 vs. $18-30)$ & $0.34(0.27-0.42)$ & $\begin{array}{l}< \\
.001\end{array}$ \\
\hline Male gender & $0.73(0.61-0.87)$ & $<.001$ \\
\hline $\begin{array}{l}\text { Vaccine combination (ChAdOx }+ \text { ChAdOx vs. BNT162b2 }+ \\
\text { BNT162b2) }\end{array}$ & $2.48(2.08-2.94)$ & $\begin{array}{l}< \\
.001\end{array}$ \\
\hline $\begin{array}{l}\text { Vaccine combination (mRNA-1273 + mRNA-1273 vs. ChAdOx }+ \\
\text { ChAdOx) }\end{array}$ & $1.13(0.08-1.58)$ & ns \\
\hline $\begin{array}{l}\text { Vaccine combination (ChAdOx + BNT162b/ mRNA-1273 vs. } \\
\text { mRNA-1273 + mRNA-1273) }\end{array}$ & $1.72(1.25-2.37)$ & $\begin{array}{l}< \\
.001\end{array}$ \\
\hline $\begin{array}{l}\text { Male gender } \times \text { vaccine combination } \\
(\text { ChAdOx }+ \text { ChAdOx vs. BNT162b2 + BNT162b2) }\end{array}$ & $1.28(0.91-1.80)$ & ns \\
\hline $\begin{array}{l}\text { Male gender } \times \text { vaccine combination } \\
(\text { mRNA-1273 + mRNA-1273 vs. ChAdOx + ChAdOx })\end{array}$ & $0.75(0.38-1.49)$ & ns \\
\hline $\begin{array}{l}\text { Male gender } \times \text { vaccine combination } \\
(\text { ChAdOx }+ \text { BNT162b/ mRNA-1273 vs. mRNA-1273 + mRNA- } \\
1273)\end{array}$ & $1.06(0.56-2.01)$ & ns \\
\hline
\end{tabular}


Frequency of incapacity to work of one or more days (none vs. after either one vs. after both vaccinations)

Based on 5153 vaccine combinations with complete information

\begin{tabular}{|c|c|c|}
\hline Age (31-40 vs. $18-30)$ & $0.72(0.60-0.86)$ & $\begin{array}{l}< \\
.001\end{array}$ \\
\hline Age (41-50 vs. $18-30)$ & $0.56(0.47-0.67)$ & $\begin{array}{l}< \\
.001\end{array}$ \\
\hline Age (51-60 vs. $18-30)$ & $0.43(0.36-0.51)$ & $\begin{array}{l}< \\
.001\end{array}$ \\
\hline Age (> 61 vs. $18-30)$ & $0,42(0.31-0.56)$ & $\begin{array}{l}< \\
.001\end{array}$ \\
\hline Male gender & $0.73(0.58-0.92)$ & .008 \\
\hline $\begin{array}{l}\text { Vaccine combination (mRNA-1273 }+ \text { mRNA-1273 vs. } \\
\text { BNT162b2 + BNT162b2) }\end{array}$ & $1.64(1.09-2.46)$ & $\begin{array}{l}< \\
.001\end{array}$ \\
\hline $\begin{array}{l}\text { Vaccine combination (ChAdOx }+ \text { ChAdOx vs. mRNA-1273 + } \\
\text { mRNA-1273) }\end{array}$ & $1.43(0.92-2.23)$ & ns \\
\hline $\begin{array}{l}\text { Vaccine combination (ChAdOx + BNT162b/ mRNA-1273 vs. } \\
\text { ChAdOx + ChAdOx) }\end{array}$ & $1.57(1.24-1.99)$ & $\begin{array}{l}< \\
.001\end{array}$ \\
\hline $\begin{array}{l}\text { Male gender } \times \text { vaccine combination } \\
(\text { mRNA-1273 + mRNA-1273 vs BNT162b2 + BNT162b2) }\end{array}$ & $2.25(1.00-5.06)$ & .050 \\
\hline $\begin{array}{l}\text { Male gender } \times \text { vaccine combination } \\
(\text { ChAdOx + ChAdOx vs. mRNA-1273 + mRNA-1273) }\end{array}$ & $0.51(0.21-1.23)$ & ns \\
\hline $\begin{array}{l}\text { Male gender } \times \text { vaccine combination } \\
(\text { ChAdOx }+ \text { BNT162b } / \text { mRNA-1273 vs. ChAdOx + ChAdOx })\end{array}$ & $1.21(0.76-1.94)$ & ns \\
\hline
\end{tabular}




\begin{tabular}{|c|c|c|}
\hline Gender: & $\begin{array}{l}\square \\
\square \\
\square\end{array}$ & $\begin{array}{l}\text { Woman } \\
\text { Man } \\
\text { Diverse }\end{array}$ \\
\hline Age: & $\begin{array}{l}\square \\
\square \\
\square \\
\square \\
\square\end{array}$ & $\begin{array}{c}18-30 \\
31-40 \\
41-50 \\
51-60 \\
>61\end{array}$ \\
\hline Vaccination: & $\begin{array}{l}\square \\
\square \\
\square\end{array}$ & $\begin{array}{l}\text { First } \\
\text { Second } \\
\text { Single vaccination, recovered from COVID-19 }\end{array}$ \\
\hline Vaccine & $\begin{array}{l}\square \\
\square \\
\square\end{array}$ & $\begin{array}{l}\text { Moderna } \\
\text { Biontech } \\
\text { AstraZeneca }\end{array}$ \\
\hline Time of vaccination: & $\begin{array}{l}\square \\
\square\end{array}$ & $\begin{array}{l}\text { Morning (until } 1 \text { p.m.) } \\
\text { Afternoon (after } 1 \text { p.m.) }\end{array}$ \\
\hline $\begin{array}{l}\text { Reactions: } \\
\text { (Multiple answers possible) }\end{array}$ & $\begin{array}{l}\square \\
\square \\
\square \\
\square \\
\square \\
\square \\
\square \\
\square \\
\square \\
\square \\
\square \\
\square \\
\square \\
\square\end{array}$ & $\begin{array}{l}\text { None } \\
\text { Headache (very strong / strong / medium / low) } \\
\text { Pain at the injection site } \\
\text { Chills } \\
\text { Fever } \\
\text { General feeling of malaise } \\
\text { Unusual fatigue } \\
\text { Rash } \\
\text { Gastrointestinal complaints } \\
\text { Sweats } \\
\text { Anaphylactic reaction } \\
\text { Vertigo } \\
\text { Muscle or joint pain } \\
\text { Other: .............................................. }\end{array}$ \\
\hline Duration of Reactions: & $\begin{array}{l}\square \\
\square \\
\square \\
\square \\
\square\end{array}$ & $\begin{array}{l}\text { None } \\
1-2 \text { days } \\
\text { Up to } 3 \text { days } \\
\text { Up to } 5 \text { days } \\
>5 \text { days }\end{array}$ \\
\hline Incapacity to work: & $\begin{array}{l}\square \\
\square \\
\square \\
\square \\
\square\end{array}$ & $\begin{array}{l}\text { None } \\
1-2 \text { days } \\
\text { Up to } 3 \text { days } \\
\text { Up to } 5 \text { days } \\
>5 \text { days }\end{array}$ \\
\hline Recovered from COVID-19: & $\begin{array}{l}\square \\
\square\end{array}$ & $\begin{array}{l}\text { Yes } \\
\text { No }\end{array}$ \\
\hline
\end{tabular}

\section{Figure 1}

The list of questions in the survey (translated from German). 
Assumed grade of impairment caused by reactogenicity

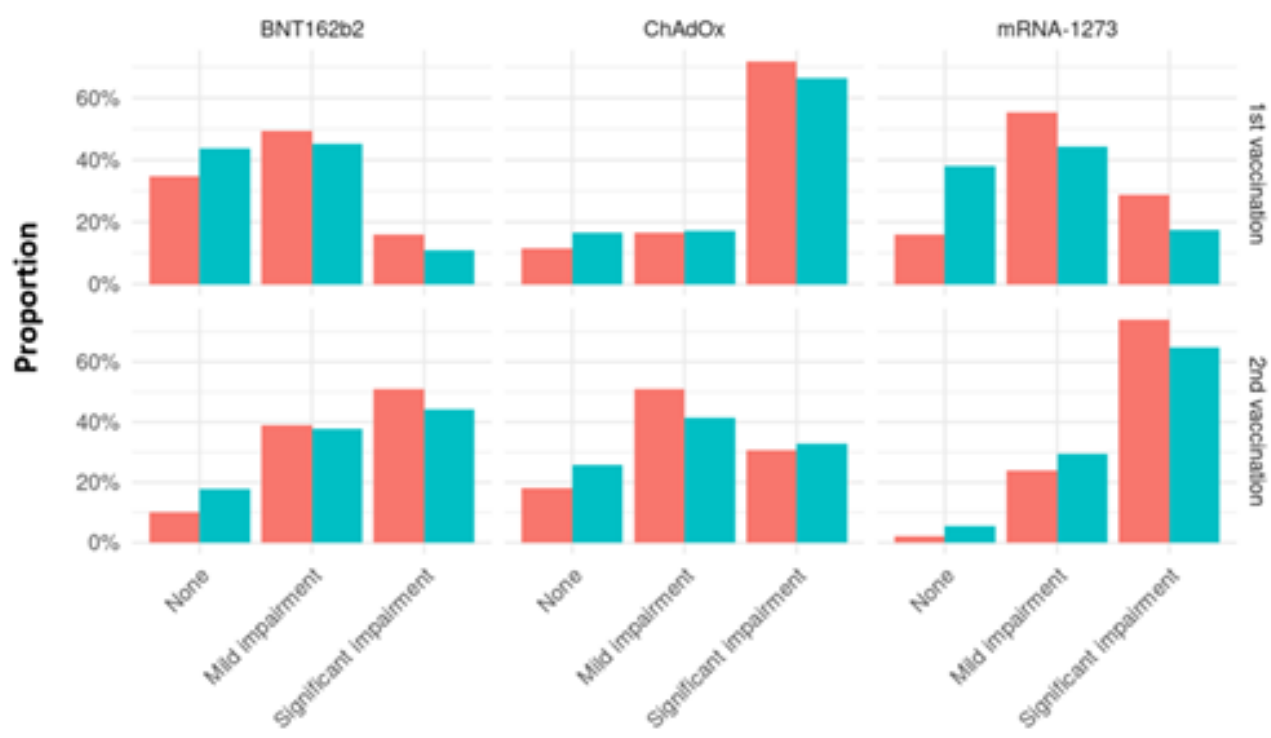

Incapacity to work

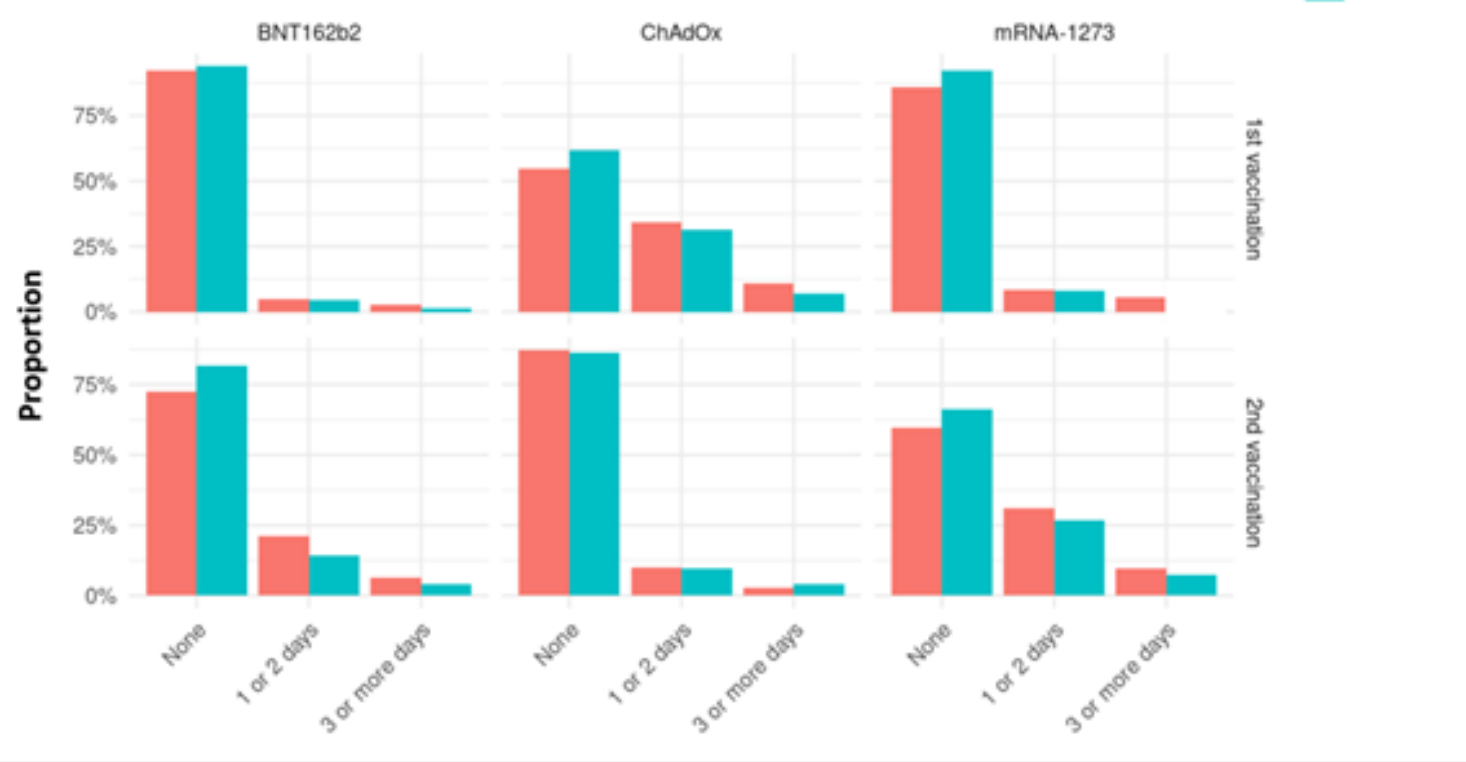

Figure 2

Reactogenicity and incapacity to work according to gender, vaccine and first versus second vaccination. 


\section{Frequency of assumed significant impairment caused by reactogenicity}

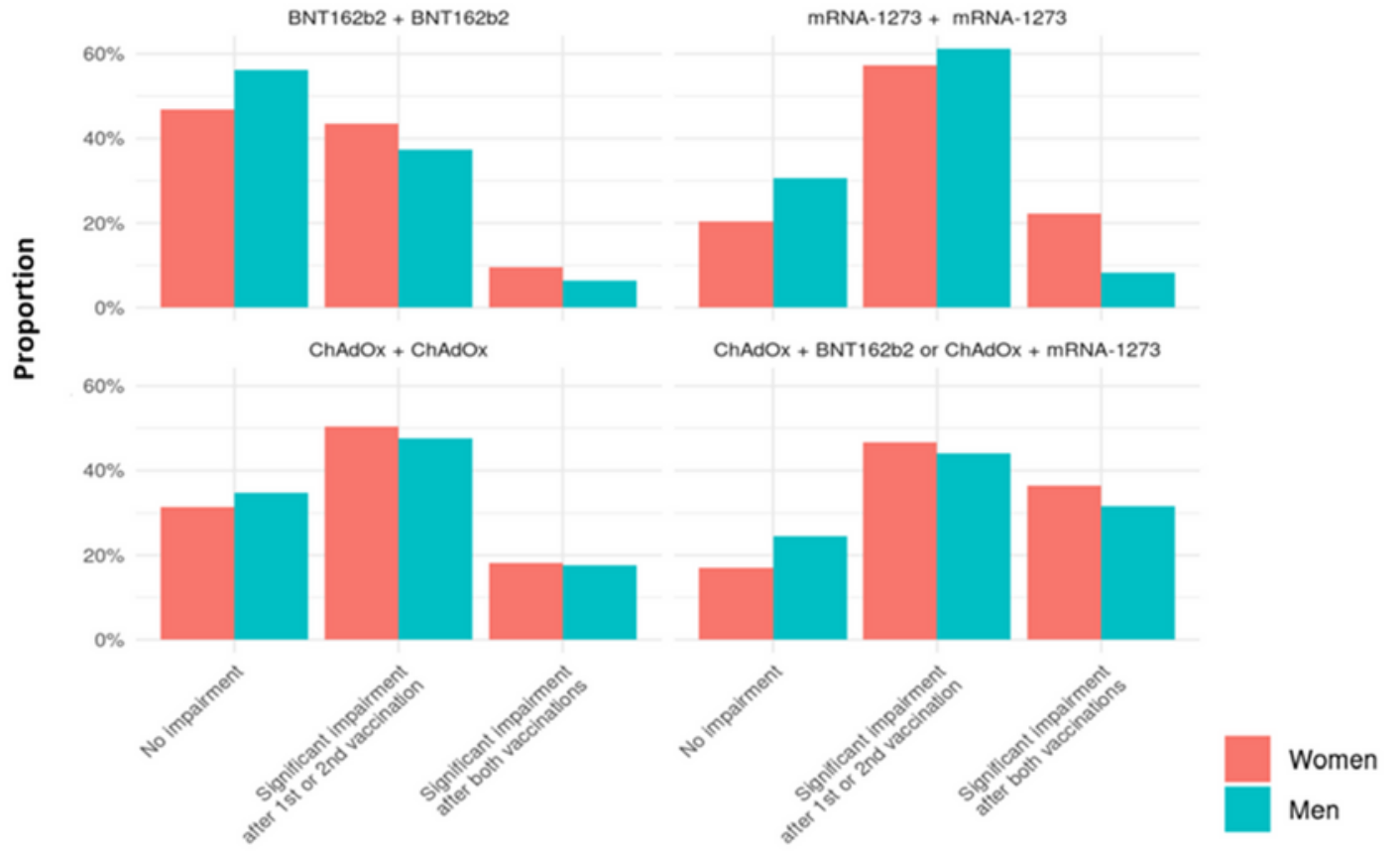

Frequency of Incapacity to work

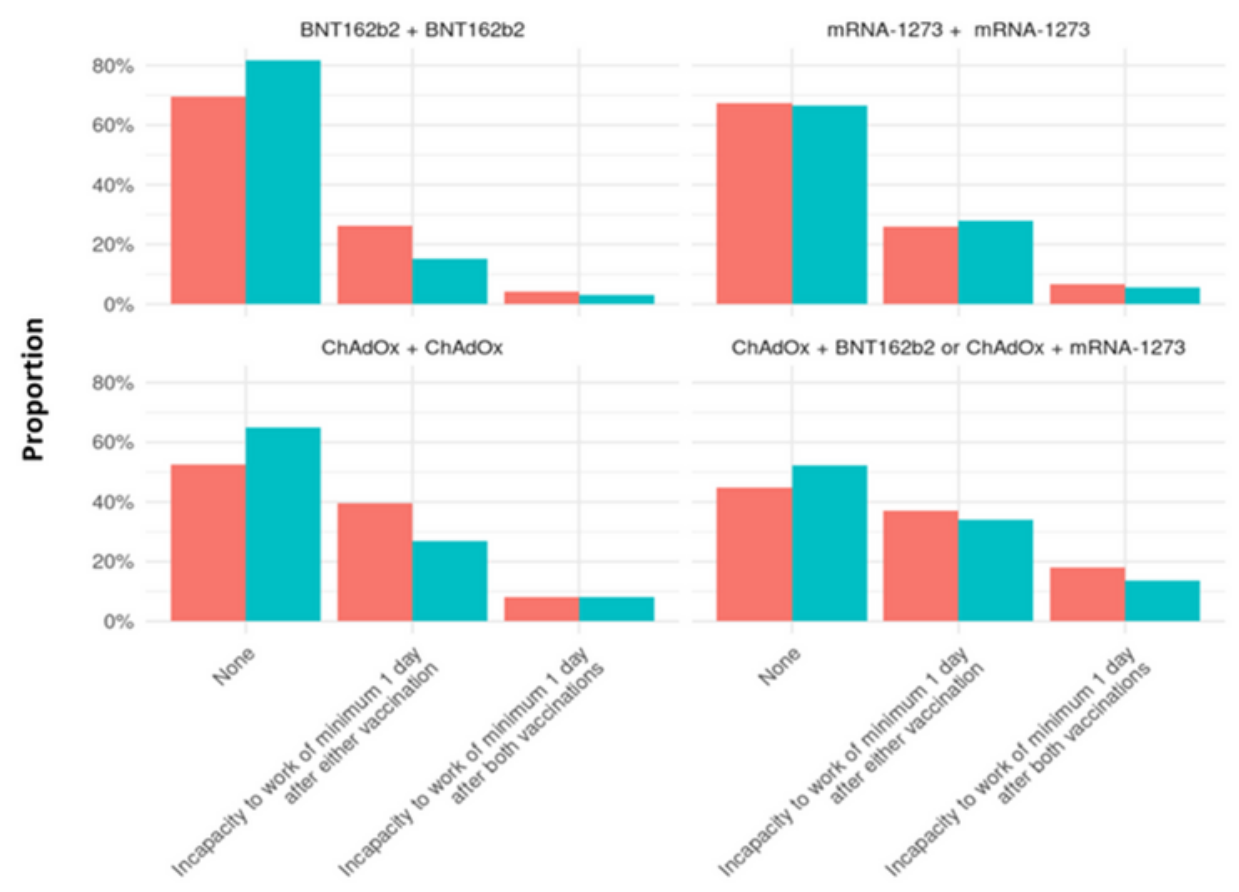

\section{Figure 3}

Reactogenicity and incapacity to work according to gender and vaccine combination.

\section{Supplementary Files}

This is a list of supplementary files associated with this preprint. Click to download. 
- GraphicalabstractgendervaccinationBMCWH.pptx 